\title{
The Characteristic of Minaret Based on Community Preference for the Composition of Mosque Architecture in Malang City
}

\author{
Wulan Astrini ${ }^{1 *}$, Herry Santosa ${ }^{2}$, Indyah Martiningrum ${ }^{3}$ \\ ${ }^{1,2,3}$ Department of Architecture, Faculty of Engineering, Universitas Brawijaya, Malang-Indonesia. \\ *Corresponding author.Email: wulanastrini@gmail.com
}

\begin{abstract}
A mosque is a place of worship for Muslims. The mosque's architectural elements include domes (roofs), mihrab, minarets, portals, and decorative ornaments. Elements of mosque architecture can express the identity of a mosque. Minaret often acts as a marker of the mosque's existence on a city scale. The minaret's design elements are the minaret head, minaret body, openings, ornaments, and structures that can be either integrated or separated from the mosque building. Five mosques located in Malang City are used as a case study in this research: Jami Great Mosque Malang, Sabilillah Mosque, Nurul Muttaqin Mosque, Ahmad Yani Mosque, and Manarul Huda Mosque. The people's preference for the characteristics of the minaret of mosque architecture in Malang City was analyzed using the conjoined analysis method. The purpose of this study is (1) Identify the variety of minaret design elements in mosque architecture in Malang City, (2) Understanding people's preferences for the composition of the minaret design elements, and (3) Analysing the characteristics of minaret based on community preference on the composition of mosque architecture in Malang City. The results showed that based on community preferences on the composition of mosque architecture in Malang City, the preferred characteristics of the minaret are (1) The shape of the minaret is a conical octagon, (2) The shape of the minaret head is a top dome, (3) The number of minarets is two, (4) Has an ornament, (5) Minaret structure is separate from the mosque building, and (6) Has an opening.
\end{abstract}

Keywords: Mosque architecture, minaret, people's preferences

\section{INTRODUCTION}

The mosque is one of the public facilities as a place of worship that grows rapidly in Indonesia. At first, there was no special requirement for the mosque building other than the function to accommodate prayer in congregation. However, over time, the mosque architecture starts to have its typology. Mosque architecture is often borrowing decorative elements of the previous building. This lendingand-borrowing process is done as long as it does not interfere with the principle of Islamic belief [1].

The mosque is not just a place of worship for Muslims but also present an aesthetic architecture design in the facade, spatial organization, and element composition arrangement of mosque architecture. The mosque was first present with a fairly simple mosque roof that is flat or gable shaped. The dome was added when Muslims felt the need to place something meaningful in their mosque [1]. This condition indicates a significant development of mosque architecture. The minaret that has a function to echo the adzan (the call to prayer) also becomes the mosque's architectural identity in addition to the dome. Mosque architecture elements can express the identity of a mosque, both in city scale, residential areas, and other public spaces. Besides, the minaret is the most strategic and best form as a marker of the presence and existence of Islam in a particular place. In the appearance of the minaret form, the influence of local traditions related to cultural ideas, and the level of skills in processing materials controlled by the community took a significant role [1].

An architectural work will never be separated itself from the condition of the society that gave birth to it, or architectural work can become an entry point to understand the social condition where the object located better [1]. It shows that the meaning of architectural works is also closely related to the perception of the human that observes them. Perception is defined as an observation process or understanding of the phenomenon that gives rise to some responses or circumstances that include cognitive and affective elements [2]. Minaret, as one of the mosque architecture's design elements, also has its constituent design elements that can be analyzed for its characteristic based on community preferences. Community preferences of minaret's characteristics become essential to be investigated because it can affect the physical form of the mosque in the future, which represents the value of the locality. Previous research on perceptions and preferences stated many factors that affected a person in choosing architectural works. According to Soenarto [3], the factors that influence a person in choosing an architectural work are taste, 
location, the scope of community, accessibility to workplaces, and the social sphere.

One of the big cities in East Java-Indonesia, Malang is in the middle of aggressively carrying out the development of public facilities, including mosques. There are five mosques used as a case study in this research: Jami' Malang Great Mosque, Sabilillah Mosque, Nurul Muttaqin Mosque, Ahmad Yani Mosque, and Manarul Huda Mosque.

\section{RESEARCH METHOD}

The research uses a quantitative method with conjoint analysis. According to Creswell [4], quantitative research is a method to test theories by examining the relationships between variables. Conjoint analysis usually applied to the research of community preference for a product. In this case, the conjoint analysis applied to get to know the community preference for the elements contained in a mosque. Data collection through questionnaires distributed to respondents in each sample mosque, then analyzed using conjoint analysis. The area and research objects are shown in Table 1.

Table 1 Research objects

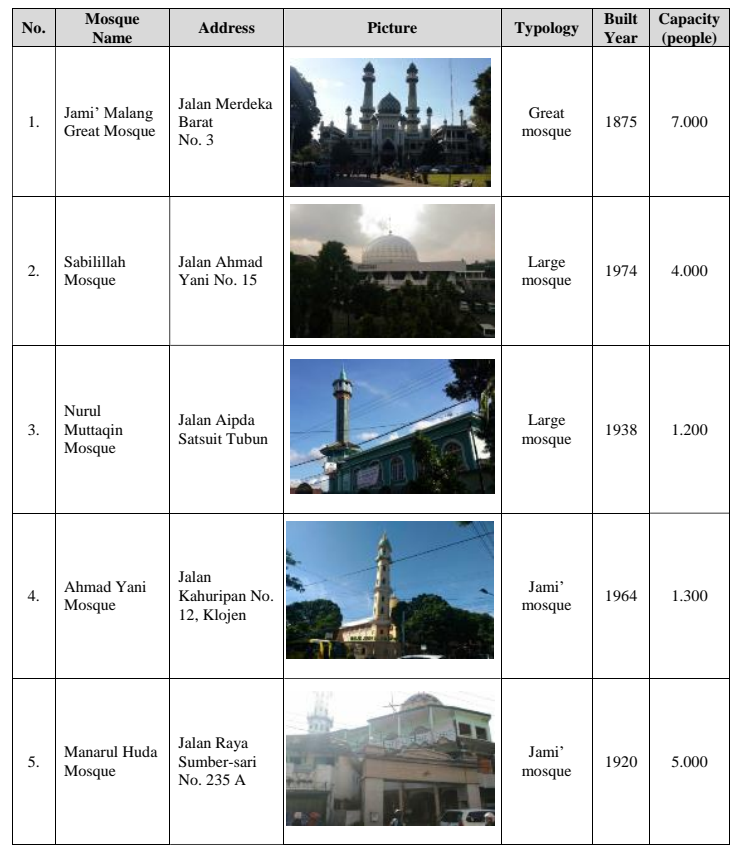

The respondents of this study are the community, where the total samples of the respondents are 90 people, divided into three categories, namely (1) Academics and practitioners in the field of architecture, (2) Islamic religious figures and mosque committee/ takmir, and (3) The general public: worshipers and students of architecture. The research variables are described in Table 2 .

The primary data collection method uses observation to obtain data in the form of photo documentation and data on the condition of the sample mosque and its minarets. The observation instruments are drawing paper, drawing tools, and distance meter. Also, this research uses a survey method with instruments in the form of a Likert scale 1-5 (Dislike very much - like very much). The data collected from the respondent through questionnaires were then analyzed using conjoint analysis. In this study, the conjoint model used is a full profile that combines the levels of all attributes into one stimulus. The result of the conjoint analysis shows that the community preferences for the composition of the minaret design at the facade level. The minaret characteristics are then examined by referring to the existing theories. The analyzed attributes are including the shape of minaret's head, the shape of minaret's body, the type of the openings, the type of the ornaments, the number of the minarets, and the structure of the minarets.

Table 2 Research variable and sub variable

\begin{tabular}{|ll|l|}
\hline \multicolumn{1}{|c|}{ Variables } & \multicolumn{1}{c|}{ Subvariables (attributes) } \\
\hline 1. Minaret's head & The shape of the minaret's head \\
\hline 2. & Minaret's body & $\begin{array}{l}\text { The shape of the minaret's body } \\
\text { Opening (exist or not) } \\
\text { Ornaments (exist or not) }\end{array}$ \\
\hline 3. & $\begin{array}{l}\text { The number of } \\
\text { the minaret }\end{array}$ & $\begin{array}{l}\text { Integrated or separated with the } \\
\text { main building }\end{array}$ \\
\hline structure & Minaret's & \\
\hline
\end{tabular}

\section{RESULT AND DISCUSSION}

The five mosques of the research objects have various forms of minarets. The identification of the minaret design elements is described as follow:

\subsection{Minaret of Jami' Malang Great Mosque}

The Jami' Malang Great Mosque has two minarets of $\pm 32,5 \mathrm{~m}$ height, and both are integrated with the mosque building. The head/ top of the minaret is an Indo-Persian dome. The minaret body is a conical octagon with three balconies, openings with an arch or curly circular and curved, as well as geometric ornaments of a rhombus. The minarets base is a pulpit, so it is higher than the ground surface.

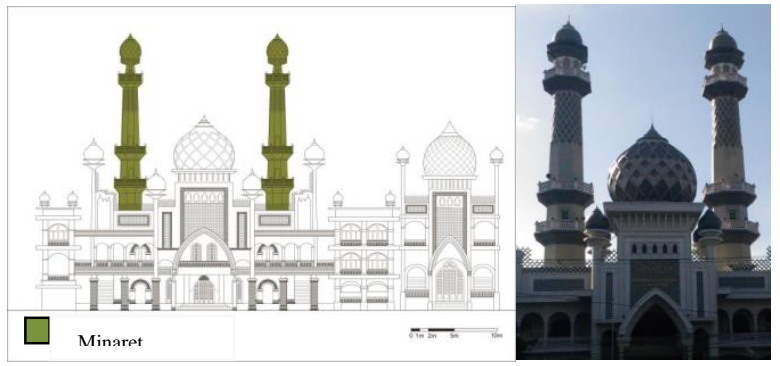

Figure 1 The picture and placement of the minaret of Jami' Malang Great Mosque 


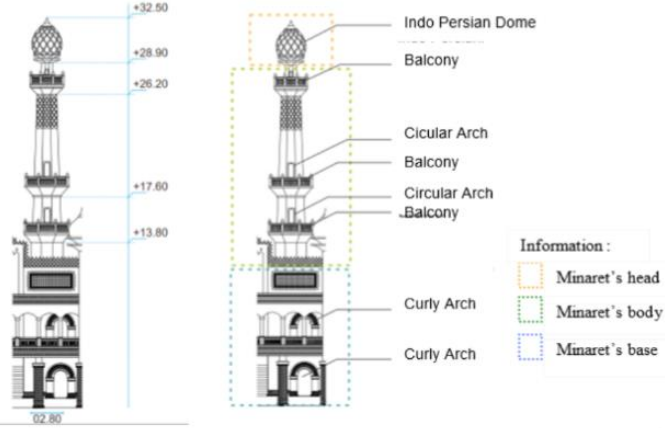

Figure 2 Elevation and design element's detail of the minaret of Jami' Malang Great Mosque

\subsection{The Minaret of Sabilillah Mosque}

The minaret of the Sabilillah Malang Mosque has a height of $\pm 45 \mathrm{~m}$. The minaret is divided into two parts, the body and the head of the minaret. The body is a 38 meters high hexagon. On the body part, there are four rectangular openings on each side and arranged vertically. The distance between the openings is the same, but its placement on each side of the minaret's body is different. The Minaret uses white ceramic as its material. The head of the minaret is a balcony with a circular base and a flat roof. Above the balcony, there is a pointed pole.

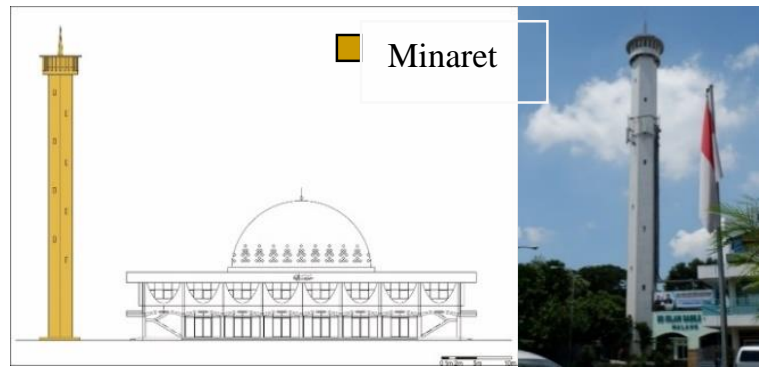

Figure 3 The picture and placement of the minaret of Sabilillah Mosque

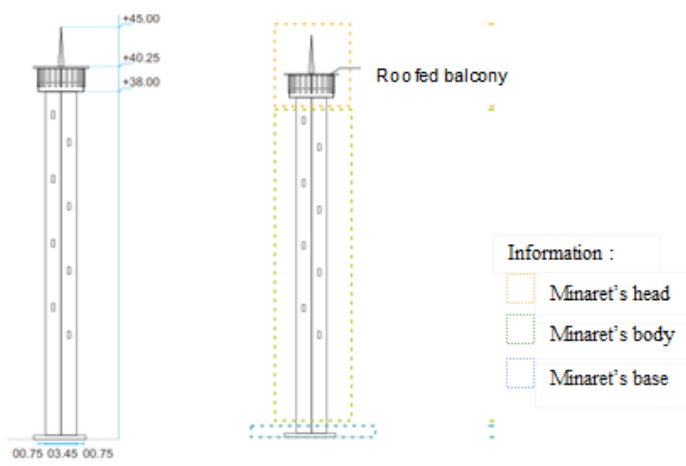

Figure 4 Front elevation and design element's detail of the minaret of Sabilillah Mosque
The minaret of the Sabilillah Malang Mosque has a height of $\pm 45 \mathrm{~m}$. The minaret is divided into two parts, the body and the head of the minaret. The body is hexagon in shape, with 38 meters high. On the body part, there are four rectangular openings on each side and arranged vertically. The distance between the openings is the same, but its placement on each side of the minaret's body.

\subsection{The Minaret of Nurul Muttaqin Mosque}

The shape of the minaret at Nurul Muttaqin is an octagon with $\pm 22,3 \mathrm{~m}$ in height. There is only one minaret located at the southeast end of the mosque, and the structure is integrated with the mosque. The minaret can be divided into three parts. The first one is the minaret base for which is integrated with the mosque. It has an opening made of ventilated blocks, also has geometric ornaments in the form of squares and circles that arranged repeatedly. The second part is the minaret body, where there is a balcony with a tiled roof. The third part is the head/top of the minaret. There is a balcony with a smaller size than the one in the body.

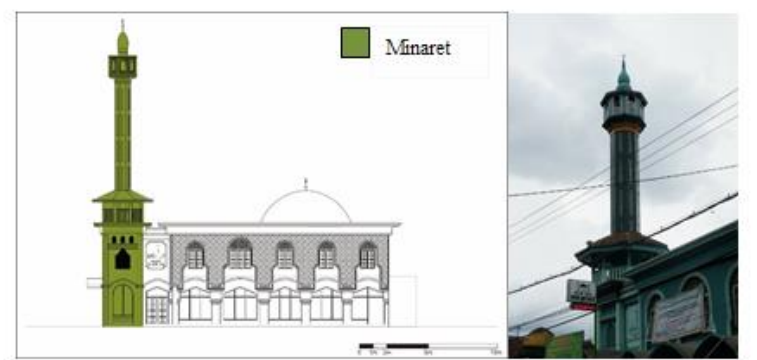

Figure 5 The picture and the placement of the minaret of Nurul Muttaqin Mosque
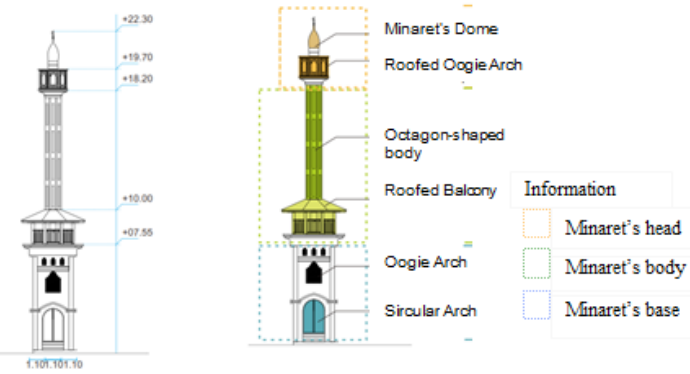

Figure 6 Front elevation and design element's detail of the minaret of Nurul Muttaqin

\subsection{The Minaret of Ahmad Yani Mosque}

The minaret of the Ahmad Yani Mosque has a height of $\pm 26 \mathrm{~m}$, a conical pentagon. The mosque only has one minaret, and the structure is separated from the mosque building. The base of the minaret is integrated with the ablution room and toilet. The body part of the minaret is divided into three segments, which in every segment, there 
is an arch and intricate geometrical ornaments. On the top of the minaret, there is a Persian styled dome with ornaments on the neck of the dome in the form of zigzag lines resembling flower petals. On the top of the Persian dome, there is an ornament in the form of a two stacks of small domes with a straight vertical line top.

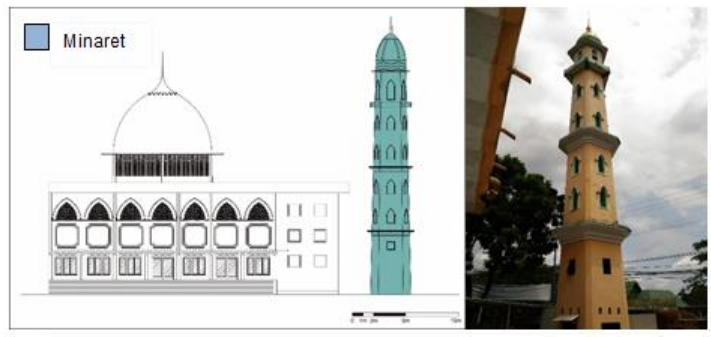

Figure 7 The picture of the minaret and its placement on Ahmad Yani Mosque

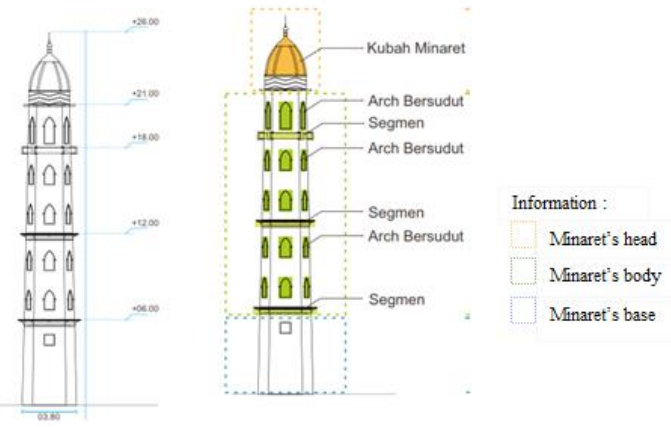

Figure 8 Front elevation and design element's details of the minaret of Ahmad Yani Mosque

\subsection{The Minaret of Manarul Huda Mosque}

The Minaret of Manarul Huda Mosque is 22,7 m in height with a conical octagonal shape. There is only one minaret in this mosque. The minaret structure is integrated with the mosque building, especially at the base of the minaret. One the minaret base, there are openings and eaves in the form of circular arches. The body of the minaret is divided into 3 (three) segments that are separated by two balconies, where the lower balcony has a larger diameter than the upper balcony. On the body of the minaret, there is also a rhombus-shaped and a combination of circular-rectangular shaped opening. In contrast, the upper body of the minaret, which bordering the head of the minaret has a living arch (circular). The top of the minaret is in the form of an onion-shaped (Indo-Persian style) dome. On top of the dome, there are ornaments arranged vertically upwards in the form of 3 (three) solid spherical geometries and crescent ornaments.

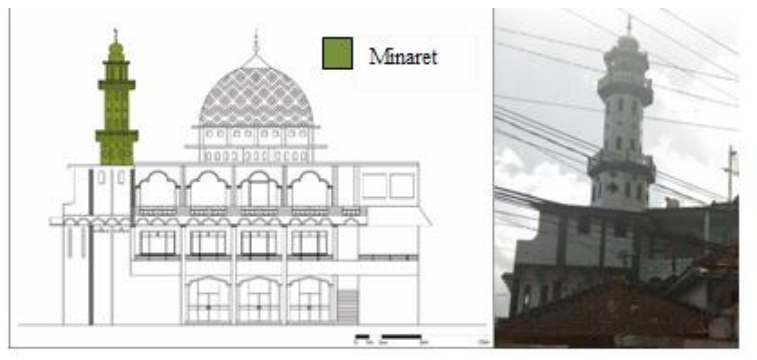

Figure 9 The picture and placement of the minaret of Manarul Huda Mosque

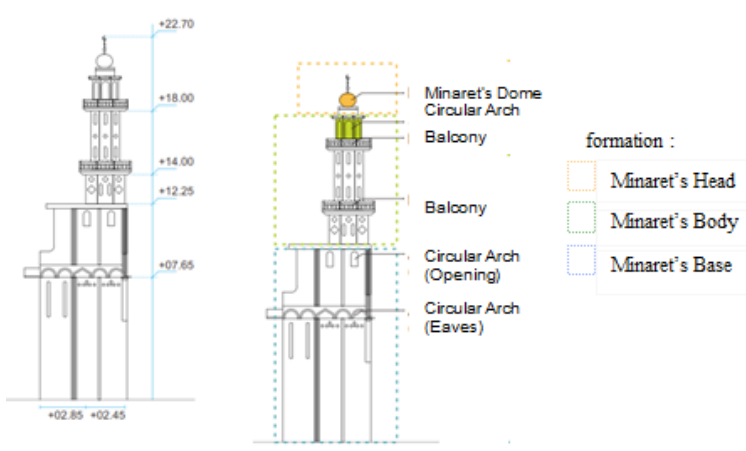

Figure 10 Front Elevation and Design Element's Detail of the Minaret of Manarul Huda Mosque

The result of the identification of various minaret design elements of mosques in Malang City as described above then can be categorized as attributes or factors in conjoint analysis. At the same time, the variety of elements are subattributes, as shown in Table 3 .

Table 3 Research attributes and sub attributes (minaret's design elements)

\begin{tabular}{|c|c|c|c|}
\hline No. & $\begin{array}{l}\text { Minaret's } \\
\text { Element }\end{array}$ & Attributes & Sub Attributes \\
\hline \multirow{3}{*}{1.} & \multirow{3}{*}{$\begin{array}{l}\text { The head } \\
\text { of the } \\
\text { minarets }\end{array}$} & \multirow{3}{*}{ Shapes } & $\begin{array}{l}\text { onion dome (Indo- } \\
\text { Persian style) }\end{array}$ \\
\hline & & & top dome (Persian style) \\
\hline & & & balcony \\
\hline \multirow{8}{*}{2.} & \multirow{8}{*}{$\begin{array}{l}\text { The body } \\
\text { and the } \\
\text { base of the } \\
\text { minarets }\end{array}$} & \multirow{4}{*}{ Shapes } & conical pentagon \\
\hline & & & hexagon \\
\hline & & & octagon \\
\hline & & & conical octagon \\
\hline & & \multirow{2}{*}{ Opening } & existed \\
\hline & & & not existed \\
\hline & & \multirow{2}{*}{ Ornaments } & existed \\
\hline & & & not existed \\
\hline \multirow[b]{2}{*}{3.} & \multirow{2}{*}{$\begin{array}{l}\text { The } \\
\text { number of } \\
\text { the minaret }\end{array}$} & \multirow{2}{*}{$\begin{array}{l}\text { The number } \\
\text { of the } \\
\text { minaret }\end{array}$} & 1 \\
\hline & & & 2 \\
\hline \multirow{2}{*}{4.} & \multirow{2}{*}{$\begin{array}{l}\text { Minaret's } \\
\text { structure }\end{array}$} & \multirow{2}{*}{$\begin{array}{l}\text { Minaret's } \\
\text { structure }\end{array}$} & integrated \\
\hline & & & separated \\
\hline
\end{tabular}


The conjoint analysis also assesses the factor or attributes that are most considered relevant by the respondents. By knowing the score of the relative importance of the respondents, the researcher can consider stimuli with factors that are considered more important and sacrifice the factors that are considered less important. It is indicated by the importance value, as shown in Table 4 .

Table 4 Importance Value Factor

\begin{tabular}{|l|r|}
\hline \multicolumn{1}{|c|}{ Factor } & Importance value \\
\hline Head of the minaret & 22,71 \\
\hline Shape of minaret & $\mathbf{2 4 , 5 3}$ \\
\hline Openings & 9,31 \\
\hline Ornaments & 13,32 \\
\hline Number of minarets & 18,13 \\
\hline Minaret's structure & 12,02 \\
\hline Averaged Importance Score \\
\hline
\end{tabular}

Based on the importance value table above, it is shown that the shape of the minaret factor has the highest relative importance value if $24,53 \%$. Furthermore, the factors considered to be the lower importance are from the largest to the smallest in a sequence, namely the shape of the head of the minaret $(22,71 \%)$, the number of minarets $(18,13 \%)$, ornaments $(13,32 \%)$, minaret structure $(12,02 \%)$, and openings $(9,31 \%)$. The level of importance of the minaret design elements from the highest to the lowest is shown in Figure 11.

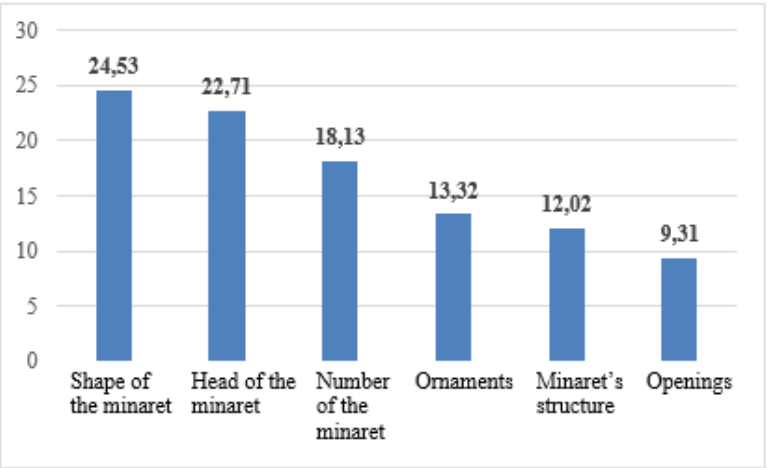

Figure 11 The design element of a minaret with importance value from the highest to the lowest

The synthesis characteristic of minarets based on community's preference is as follow:

1. The shape of the minaret

The shape of the minaret, which becomes community preference, is the octagonal cone. This shape can be represented as the minaret shape of the Jami Malang Great Mosque or the Qusun tower in Cairo [5].

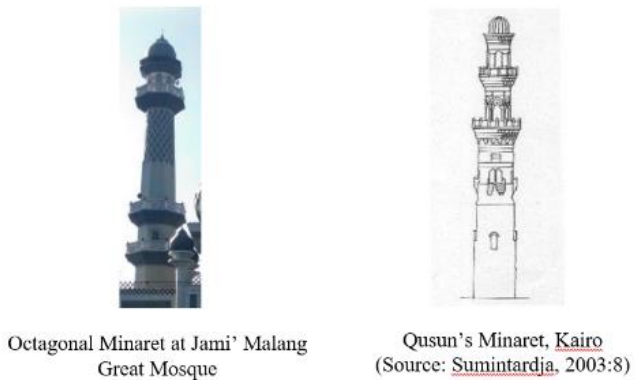

Figure 12 The shape of the minaret based on community preference

2. The top of the minaret's shape

The head/top of the minaret, which is the people's preference is in the form of a top, where the shape of the dome is in Persian Style. According to Fanani [1], the Persian dome has a conical feature at the tip, while at the bottom is a cylindrical circle like the neck of the dome [1]. The exterior and the interior are given a floral mosaic decoration. The characteristic of a minaret with top head can be represented as in the minaret at Ahmad Yani Mosque.
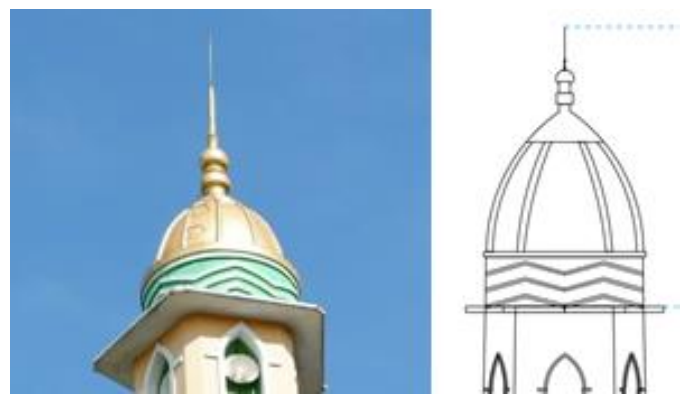

Figure 13 The shape of minaret's head based on community preference

3. The number of the minaret

The characteristic of the number of minarets that become the community preference is two minarets. These characteristics can be represented as in the Jami' Malang Great Mosque.

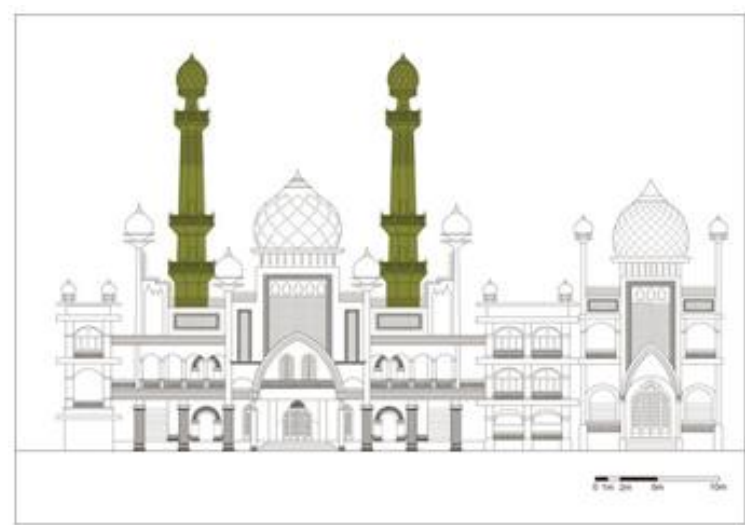

Figure 14 The number of minarets based on community preference 


\section{Ornament}

The characteristics of the ornament that become the community preference are the minaret that has ornaments on it. The ornaments are a variety of decorative art that can provide aesthetic value to the overall minaret design. Based on the analysis result, the ornaments of the minaret can be categorized as:

a. Ornaments on the head/top of the minaret

Ornaments in the head/top of the minaret can be rhombus geometrical ornament, the crescent moon at the top of the dome, and zigzag line on the dome's neck.
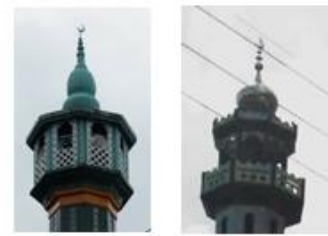

Crescent moon ornaments on the tip of minaret's dome

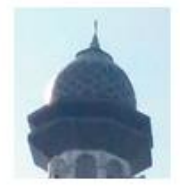

Rhombus Geometrical

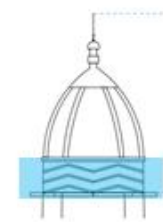

Zugzag Line

Figure 15 The ornaments on the head of the minaret based on community preference

b. Ornaments on the body of the Minaret

Ornaments on the body of the minarets can be in the shape of rhombus geometric, rectangle, and intricate.

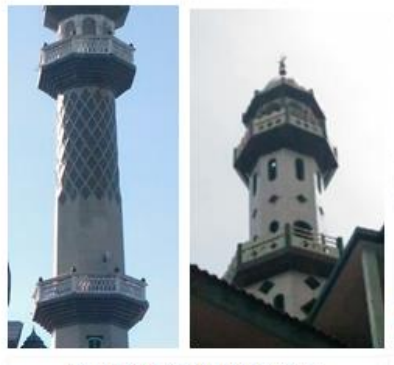

Rhombus Geometrical Ornaments

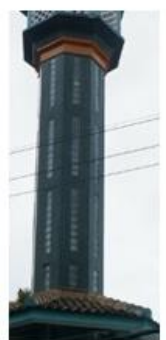

Rectangle Ornaments

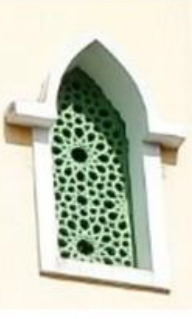

Intricate Ornaments

Figure 16 Ornaments of the body of the minaret based on community

5. The Structure of the Minaret

The minaret's structure characteristic that becomes the community's preference is the structure that separated from the mosque building. The existence of minaret that is not integrated with mosque building can strengthen the identity and the existence of the minarets and serve as a complement of the mosque building. The structure of the mosque is shown as follow:
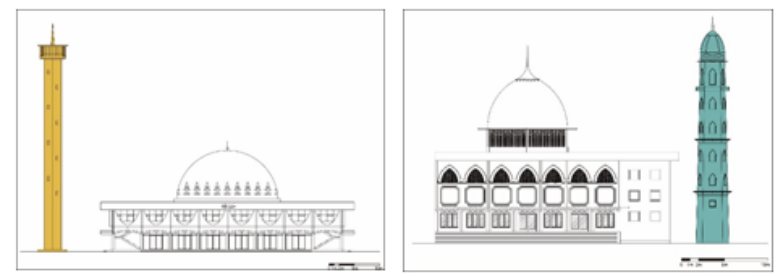

Minaret has a separated structure with the Mosque Building shown that it existence is a complement to the Mosque Building

Figure 17 Minaret's structure based on community preference

6. Opening

The opening characteristics that become the community's preference are the minaret that has openings. The types of openings that can be applied to minarets are:

a. Opening at the head/top of the minaret

The opening at the head/top of the minaret can in the form of rectangular geometry and oogie arch.
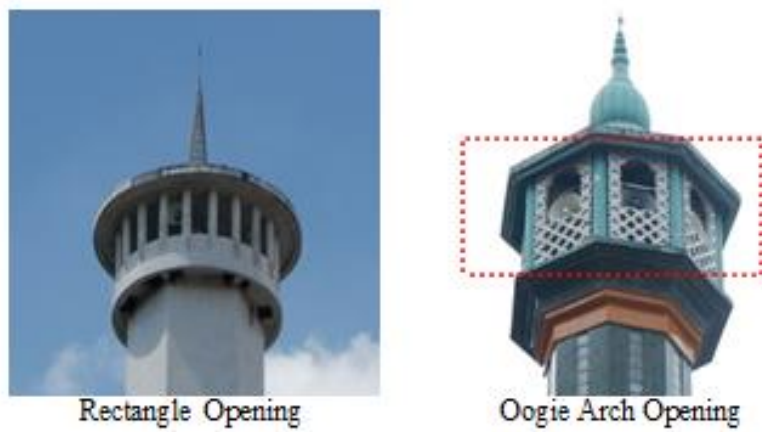

Figure 18 The opening in the top of the minaret based on community preference

b. Opening on the base of the minaret

The opening in the base of the minaret can take the form of Oogie arch, circular arch, curly arch, and rectangle.

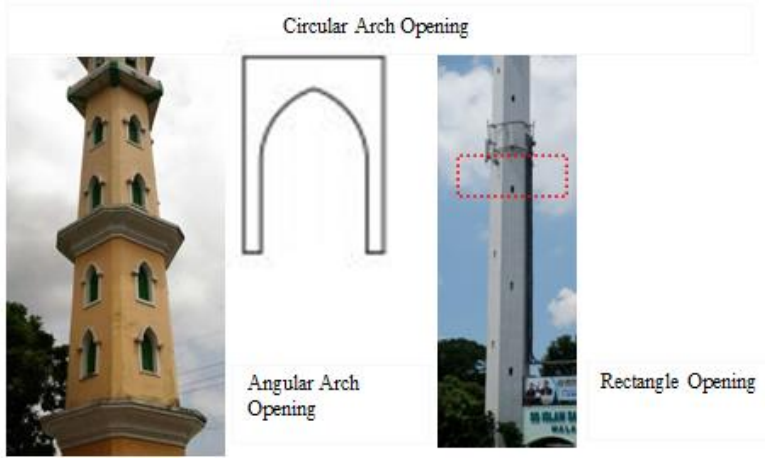

Figure 19 Opening in the body of the minaret based on community preference 


\section{CONCLUSION}

Mosque architecture can represent the locality in a place or region. The architectural elements of the mosque include dome, minaret, arch, and ornaments. At first, there is no special requirement outside the mosque building while it can be used for prayer in congregation. However, over time, the mosque architecture starts to have its typology until today. Malang is one of the major cities in East Java has 650 mosques spread across five districts. The Jami' Malang Great Mosque, Sabilillah Mosque, Nurul Muttaqin Mosque, Ahmad Yani Mosque, and Manarul Huda Mosque are five mosques which become the objects of the research. The typology of these five mosques is varied, ranging from great mosques, large mosques, and the Jami' mosques. Each mosque has minarets that functioned as a place to echo the call of prayer, a marker of the existence of a mosque, a complement to the mosque building, and a landmark of an area/city. Minarets are divided into three parts, consist of the head, body, and base.

The characteristic of the minaret that become the community preference of the composition of mosque architecture in Malang city (1). The shape of the minaret is a conical octagon, (2). The shape of the head of the minaret is top-shaped, (3). The amount of the minaret is two, (4). Has ornaments such as rhombus geometric and crescent moon on the top of the dome at the head of the minaret; has intricate geometry and rectangle geometry on its body (5). The structure is separated from the mosque building and (6). Has opening that can take form as a rectangular geometric, circular arch, oogie arch, pointed arch, curl arch, and square-shaped. The suggestion for further research is the theme for the characteristic of mosque architecture is based on community preference to explore local character both at city and province scale. The suggestion related to the aspects that can be investigated is the dome characteristic, arch characteristics, and ornamental characteristics. Similar research can be applied to the minaret of the province mosque or mosques within campus/ educational institutions.

\section{REFERENCES}

[1] Fanani, Achmad. Arsitektur Masjid, Yogyakarta: Bentang, 2008.

[2] Suminah, Nenah., Bambang Sulistyantara, Tati Budiarti, Studi Persepsi dan Preferensi Penghuni Terhadap Ruang Hijau di Rumah Susun Sederhana Sewa Provinsi DKI Jakarta serta Strategi Perbaikannya. Jurnal Lansekap Indonesia, Vol. 9, No. 1, 2017.

[3] Soenarto, Argo Utomo; Suprapti, Atik; Murtini, Titien Woro. Preferensi Masyarakat Dalam Memilih Perumahan Berdasarkan Fasade Studi Kasus :

Perumahan di Kecamatan Baki, Sukoharjo. Jurnal Arsitektur ARCADE, [S.1.], v. 1, n. 2 (2017) 77-83.
ISSN 2597-3746.

doi:https://doi.org/10.31848/arcade.v1i2.16.

[4] Creswell, John W. Research Design: Pendekatan Metode Kualitatif, Kuantitatif, dan Campuran. Yogyakarta: Pustaka Pelajar., 2016.

[5] Sumintardja, Djauhari. Makna Menara Dalam Arsitektur Islam. NALARs Volume 2 No. 1 (2003) 111. 